\title{
Opening Address of the Antiquarian Section at the Gloucester Meeting
}

\author{
E. Freshfield LL.D., F.S.A.
}

To cite this article: E. Freshfield LL.D., F.S.A. (1890) Opening Address of the Antiquarian Section at the Gloucester Meeting, Archaeological Journal, 47:1, 268-289, DOI:

10.1080/00665983.1890.10852429

To link to this article: http://dx.doi.org/10.1080/00665983.1890.10852429

Published online: 15 Jul 2014.

Submit your article to this journal $₫$

Q View related articles $\square$ 


\section{OPENING ADDRESS OF THE ANTIQUARIAN SECTION AT THE GLOUCESTER MEETING. ${ }^{1}$}

By E. FRESHFIELD, LL.D., F.S.A.

I shall, in the few words in which $I$ am about to address you, confine myself to those topics which have come within my personal observation during the past year, taking each of them as a sort of starting point, for I think that my address should, in part at all events, be a sort of resume of the past year.

It might be thought that in such a well worked field as that of England it was not possible to find any new or startling thing, but any one who heard a paper which was read by Mr. A. J. Evans, the distinguished son of a distinguished father, at the Society of Antiquaries, in March last, must have at once had any such feeling dispelled. Mr. Evans, who has been pursuing certain excavations at Aylesford, in North Kent, came across a series of groups of interments containing urns of a class which had hitherto bien called by the name of late Celtic. The description of the interments and the ornamentation of the urns led him to the conclusion that these interments were entitled to a separate and distinct denomination. I cannot do more than in the most general way describe what he shadowed out in his paper, which will be printed in Archoologia. It was to the effect that this species of interments could be identified as that of a separate and distinct race, which he believed to be Belgic. It was, of course, no new thing to be told that there was an incursion of Belgæ into England. The novelty of Mr. Evans's discovery was to be able to identify the interments of this race. He connects this class of interment in various ways-partly by the manner in which the urns are grouped, partly by the forms of the urns, and partly

${ }^{1}$ Read at the Annual Meeting of the Institute, at Gloucester, August 12th, 1890. 
by their contents with similar interments on the other side of the Channel. Coupling this with the peculiar forms of the vases in which the interments were made, he traces the race through the north of France to the upper part of the Adriatic, following pretty much in the same route as a person travelling from London to Venice by the Saint Gothard route would now travel. Mr. Evans is not a person to leave so interesting a subject without having thoroughly investigated it, and we may look forward to a distinct addition to our knowledge of the inhabitants of this country at a time shortly preceeding the first Roman Invasion, to a knowledge also of the history of the people who went to compose the English race who resisted Julius Cæsar on his landing.

I believe it is not likely that traces of the Belgæ will be found so far westward as this. We, in the east of England, are, of course, more directly interested in them. Some authors have attributed to them the construction of the great wall which turned the northern half of Romney Marsh into the fertile plain which it now is.

Upon this plain many Roman remains have been found, so that it is quite certain that the wall existed in their time, but it is, of course, possible that it may be their work and not that of the Belgæ; however, as I have said before, Mr. Evans is not the man to leave any subject which he has made his own incomplete, and we may look upon this discovery as only the opening page of the history of the Belgæ in England. Here I find I am trespassing on the historical ground of my dear friend the Dean of Gloucester.

I will only add that for my part I am looking forward to something of this sort. When I was a boy I was taught that the ancient Britons who resisted Julius Cœsar wore flowing white robes, and were dressed in the skins of animals. I expect every day to be told that the flowing white robes were smock frocks, and the skins of animals were leather gaiters. I have seen some ancient Britons still in this uniform in the eastern part of England. Speaking of digging I am led to mention a project which has been set on foot by the Society of Antiquaries and is now in active work, and to which I, for my part, intend to give my cordial assistance-I mean the excava- 
tion of Silchester. This is no place to discuss whether Silchester is Calleva or some other town; I shall refrain from expressing any opinion for fear it should lead to a discussion. Of one thing there is no doubt, that in the fields under the surface there are the remains of a large Roman town, divided, like all Roman towns, into squares. It is at all events worth while to uncover this space to see what the foundations will teach us. For my part I do not expect to find anything startling. I shall be surprised if the result is not to disclose the fact that a Roman town must have looked very much like, say, such a town as Cordova does now-that the shops were gathered together in bazaars like the remaining Imperial Bazaar at Constantinople, and that the houses themselves were not unlike in their shape and arrangements to the houses of a French provincial town, only the modern houses have no bath and are much less comfortable and not so well warmed.

The excavation is in good hands, but I may be permitted to express a hope that as the sites are uncovered perfect plans and drawings will be taken of everything, and an accurate description of what is found made, and that each site will then be covered up again before the frost gets to the masonry and destroys it. I do not know a more pitiful sight than the Roman mosaic at Bignor presents. Most probably we shall settle for once and all what Silchester was and what its name was.

I have said that arrangements have been made not only for commencing the excavation at once, but for proceeding with them in the summer. I am sure the Committee which has been formed for the purpose will welcome the assistance of any Members of this Institute and of the two Societies who may wish to take part in this. They will at all events learn something to aid them in the excavations they may hereafter make nearer at home.

I will now turn to a very different subject, though it, too, in a sense, is in the same connection. Most of us here present will have heard, and some of us will have seen the most extraordinary collection of archiepiscopal vestments which were found in a tomb at Canterbury, which I now think is sufficiently identified as that of Archbishop Hubert Walter. On opening what was believed to be a cenotaph the authorities discovered the remains of an 
Archbishop in full dress and undisturbed. One of two courses remained, either to close the tomb at once, or to do what the authorities did, to reverently remove the vestments for preservation. I think in a learned society like this we can have no hesitation in saying that in the circumstances the authorities adopted the right course.

The Archbishop was dressed with a mitre on his head with a crozier by his side, portions of the chasuble, amice and stole were found. The fastenings of his pall were there, and sufficient of the pall to prove its existence. He had long stockings or buskins of silk, and slippers of the same material. He had a ring on his finger and a paten and chalice by his side. The only regret $I$ feel is that he was not photographed immediately on discovery.

The whole of these interesting antiquities have been lent by the authorities to the Society of Antiquaries of London, and it is the intention of the society to illustrate the whole of these vestments in a part of the Vetusta Monumenta, and I hope to compare them with similar vestments which are in existence.

Hubert Walter was Archbishop of Canterbury during the reign of King Richard I. and King John, and died in 1205, nearly at the time when King John lost his Norman possessions. He had been a personal friend of and companion of King Richard to the Holy Land, and had negotiated his ransom. During his reign he occupied a position in England, during the King's absence in Normandy, similar to that now occupied by the Lord Lieutenant of Ireland. He was, therefore, in addition to his high ecclesiastical rank, a person of very high position, and at all events he possessed this merit, that none of the turmoils which marked the archiepiscopates of his predecessor and successors took place in his time. He was succeeded as Justiciar by Geoffrey FitzPeter, and the extent to which the two restrained King John may be gathered from the King's remark on the death of the latter-" When he arrives in hell," said the King, "he may go and salute Hubert Walter, for, by the feet of God, now for the first time am I King and Lord of England."Stubbs's Const. Hist., vol. i, p. 591. But here again I am touching on historical ground.

One thing that interested me much was the extent to 
which, even in the twelfth and thirteenth centuries, we drew upon other countries for our supplies. As I have said, the whole of the dress of the Archbishop was of silk with some portions of cloth of gold. The silk, of course, is a foreign product, and the ornamentation of some of it seemed to me to be of foreign, probably Byzantine, workmanship. The slippers of embroidered silk were ornamented with carbuncles and amethysts, neither of them English products. The pall was, I suppose, made of Italian wool. The crozier staff of cedar wood.

Upon the Archbishop's finger was a ring, the stone of which, a hard green stone, is engraved with a gnostic emblem, a serpent with a fiery head with the word "Knuphis" written under it, most probably brought by himself from the Levant. Other engraved stones were upon the top of his crozier. The border of the chasuble is of cloth of gold, beautifully embroidered with a design which seems to me to be Byzantine, but at all events not of English manufacture. I do not know that I ought to have been, but I was surprised to find the whole of the Archbishop's dress of silk.

This brings me to another class of Antiquities from Canterbury which was exhibited at the same time at the Society of Antiquaries, namely, a large collection of pieces of silk which had been the envelopes of royal letters. It appears that in the twelfth and thirteenth centuries it was the habit for the kings, in sending letters to the monastery, to enclose their epistles in pieces of silk. These pieces are all of them oriental, and one of them has a most unmistakable Chinese head upon it. It would seem from this that in the twelfth and thirteenth centuries silk was imported from China to Europe and found its way to England. It seemed to me that the silk in which the Archbishop was dressed was either Indian or Chinese, it looks very much like the silk which comes from India to England and is called Tussa silk. This is still the practice with the Sultans of Turkey. The firman, for the Turkish loans came to London in a bag of Crimson silk, probably a relic of a Byzantine custom. It is to be hoped that now the subject is under discussion it will be thoroughly exhausted.

With regard to the Archbishop's monument there is 
still a good deal to be said, and I feel sure that the able hands to which the whole matter has been entrusted, will not allow it to be dropped until all that can be suid has been. Most probably the Archbishop's monument was made by his executor, and this consideration will probably lead to the fixing of the name of the person by whom it was erected, The following memorandum which is written by my friend, Mr. F. J. Baigent, of Winchester, a real antiquary, leaves, I think, no doubt, that. Elias de Derham was the Archbishop's executor, and our knowledge of him will, I think, leave still less doubt as to the origin of the beautitul monument:-

"You are quite correct as to my having mentioned to you that Elias de Derham (or Dereham, as it is sometimes spelt) was one of the executors of the Archbishop's will. His acting executors were James de Sauvage, or Salvage, who was one of his chaplains and rector of Wrotham in Kent; and Master Elias de Derham, rector of Melton Mowbray, cannon of Sarum, \&c. The Archbishop died 13 th July, 1205, and the King appears to have gone down to Canterbury at once, probably to attend the funeral, where he arrived on Friday 15th July, and remained until the 20th, on which day exequies of the octave of the Archbishop's death were, as usual, solemnly kept.

"On the 13th August-the day of "the month's mind" -the King caused a closed letter to be written to Reginald de Cornhille, sheriff of the county of Kent, on behalf of James Salvage and Master Elyas de Derham, to wit, that he should deliver to them all the chattels of the wardships (de wardes) which the Archbishop possessed, in the Sheriff's bailiwick, on the day which he died, \&c. (Close Roll 7 John m. 7.) This was done because they claimed them as the Archbishop's executors. On the 2nd January, 1205-6, there was issued a Royal Mandate-Rex, \&c. Jacobo Salvagio et Magistro E[lie] de Derham, \&c., executoribus testamenti domini $\mathrm{H}$ [uberti] Cantuariensis Archiepiscopi, \&c., Mandamus vobis quod omni occasione et dilacione postpositis faciatis habere domino P[etro] Wintoniensi per manus W[illelmi de Wrotham] Archidiacono Tantonie et W[illelmi] de Cornhulle centum libras quas predictus H[ubertus] quondam Cantuariensis Archiepiscopus habuit die qua VOL, XLVII 
obiit de pecunia S[avarici] quondam Bathoniensis Episcopi, pro centum libris quas prefatus $\mathrm{P}$ [etrus] Winttoniensis Episcopus habere fecit de prestito, per plegium suum eidem S[avarico] Bathoniensi Episcopo habere faciatis $\mathrm{H}$ [ugoni] Archidiacono Wellensi et W[illelmo] Archidiacono Tantoniensi, custodibus Episcopatus Bathoniensis ad quietanda debita predicti S[avarici] Episcopi. Teste me ipso apud Clarendonam ij [die Januarii. Close Roll 7 John, membrane 6.

"On the 4th April, 1206, the King ordered the following letters patent to be issued, which further illustrates the fact of their being the Archbishop's executors :Rex Jacobo Salvagio et Magistro Elye de Derham, salutem. Mandamus vobis quod liberetis Reginaldo de Cornhille, mille et centum marcas de fine quem nobiscum fecistis, pro debitis domini H[uberti] quondam Archiepiscopi Cantuariensis. Et in hujus rei testimonium, has litteras nostras patentes vobis mittimus. Teste me ipso apud Dovre, iiij. die Aprilis. Patent Roll 7 John m. 5.,

"I think I have given what is quite sufficient to show that when I mentioned the circumstance that this eminent architect was exeeutor to Archbishop Hubert, and that I was inclined to attribute to him the design of that interesting tomb from his close association with the Archbishop and in the winding up of his affairs, I was not speaking at random. And if what I have written proves of interest to you and is satisfactory, I shall feel much gratified to think that I mentioned it to you, and that you have honoured me by asking for further information and taking an interest in it."

The whole of the articles found in the tomb were collected and cleaned by a person known I dare say to some of you, but to whom we Antiquaries ought to be very much indebted-I mean Dr, Sheppard, of Canterbury. I do not know how far I am at liberty to talk about what I see at the charming visits which I from time to time pay him.

Nothing can be more interesting than a visit to his sanctum (an inner library) in the Cathedral where he is. The unrivalled collection of letters, some dated in the twelfth and thirteen centuries, in his custody is most interesting. 
Upon the last occasion of a visit there Dr. Sheppard showed me a document which I hope he will some day describe. I shall only here hint at it. It was a record of a Prior who was in the fifteenth century being instructed in Greek by a Greek who had come from Constantinople after the taking of the town by the Turks. In sorting the records, Dr. Sheppard found some of the original lessons in Greek given by this Greek master to his reverend pupil, and also other Greek fragments which must have been brought over at the same time.

Whether anything of great value will be found among these is another matter, but the story is interesting, and to find traces of these early Greek lessons still more so.

The only thing which I can compare with it is a small fragment which used to be preserved in Winchester Cathedral Library. It was a page of a writing lesson which a nephew of the Dean was having at the hands of one of the notaries of the Cathedral at the time when the town was about to be occupied by the Parliamentary troops in the Great Rebellion. The writing lesson came to an end together with the notary and other things. But this again begins to savour of history. I wish there was a Dr. Sheppard in every Cathedral library; I hope there is one at Gloucester.

The subject of records is one in which I am especially interested, though more from an historical point of view than looking at them in the light of simple antiquities. Moreover the records in which I am interested are of but a low sort-parish registers, churchwardens' accounts, and vestry minute-books, and such like things.

In this connection some of you are no doubt aware that a special report has been made by a Select Committee of Antiquaries upon the best methods of preservation and publication of parochial registers and other parochial records. To my mind valuable as parish registers are they are the least interesting of all parochial records.

They are interesting only for particular purposes, and are not to my mind of the same general interest as other parochial books, the vestry minute-books and account books. The vestry minute-books of a parish, taken with the registers, may of course be specially interesting, particularly in the case of a large town. When the three sets 
of books exist together it is possible, as I think I have succeeded in showing in one or two parishes in the City of London, to form a directory of the parish at any particular period. Besides this one can ascertain by this means what part of the parish was healthy and what unhealthy, particularly in the times of plague.

The whole of the period between 1560 and 1665 was subject to violent outbreaks of plague, and as it is just during this period that the parish books were most accurately kept, it is not unlikely that some useful information may be derived from their study.

Plagues and similar visitations follow the same laws, and the parishes which were most severely visited in the sixteenth and seventeenth centuries with plague are the same which were most severely visited in this century with cholera.

The three sets of books together give also a most complete insight into parochial life during the abovenamed period.

Our parish records in the City of London are now pretty well known, and sufficient interest has been aroused in them to insure their preservation. From the fact that I sometimes see portions of the records of country parishes for sale in the various catalogues of books that are sent me, I am afraid that the same does not altogether hold good in the country. The way in which this happens is somewhat as follows. The clergyman, a bachelor, for safety's sake keeps the records in his own rectory. When he dies, his executors, whose duty it is to realize his effects, sell everything they find, and so it happens that in this way parochial property sometimes gets dispersed. I do not think the property is lost during the lifetime of the clergyman, but it does get dispersed on his death. This shows how undesirable it is for a clergyman to keep parochial property, even for safe custody, in his house. The same cause also operated in a measure with another species of interesting parochial records, I mean monumental brasses. I suppose, most of us who have been interested in brass rubbing can tell of how they have found a brass which had got detached from its matrix kept for safe custody in the rectory. But to return to the records. It seems to me that the 
duty of looking after these records is essentially the work of a local society. A Society like this, or a Society like the Society of Antiquaries, can have very little power in the preservation of country parish records, but the local knowledge possessed by the secretaries and members of local societies ought to give them a very great advantago in doing this. - I hope it will not be considered out of place if I press this upon the attention of gentlemen present, particularly those who are members of the Gloucester and Bristol Archæological Society. I know. very little of the records of Gloucester, but I am. quite sure in a city so ancient and so important there must be found in the ecclesiastical, municipal, and parochial archives a large number of very valuable records interesting both for preservation and for publication.

To begin. with, there are the Bishops' registers, which are always important and valuable documents. Some day we may hope to see all the Bishop' registers generally printed in the same way as those at Exeter have been. Not only are the registers interesting in themselves, but they throw light upon all surts of matters of antiquarian interest.

I remember an instance of this. There is a curious little church near where I live, in Surrey, which tradition points out as the church in which the first reformed Prayer-book of King Edward VI. was first used.

It is a little out-of-the-way church in the Surrey downs, about five miles due south of Croydon. Croydon was Archbishop Cranmer's country residence. Warlingham, the little church to which I allude, was in the Diocese of Winchester. The tradition is that Archbishop Cranmer, wishing to see how the service would go off, had a full rehearsal in Warlingham Church.

But how could this be Warlingham, being in the Diocese of Winchester? Stephen Gardener, Bishop of Winchester, was at that time in suspense for not accommodating himself to the new state of things, and the Bishops' register showed that the living of Warlingham was then vacant. I do not mean to say that this carried us very far on our journey, but as far as it went it showed that there was nothing in the state of things in opposition to the tradition. 
With regard to municipal records a calendar might be printed of the most important of them, and that at little cost, similar to the calendar made of the documents at Winchester. I understand there is a most excellent calendar of the documents here.

I admit that the cost of printing records makes their publication a formidable undertaking. If however, the funds of a local society do not admit of the publication of records, still a local society may do a great deal by making a calendar of them, For instance, there ought to be no great difficulty to make a calendar descriptive of the registers and parochial books in each parish in a given county. The preparation and printing of such a document ought not to be either difficult or costly. To a certain extent it might be extracted from county histories and from the publications of the local sccieties. This is a work which all could help in. When such a calendar has been made it might be checked from time to time, and there would in this way be a check upon the gradual loss which perhaps unavoidably takes place in these documents.

In addition to these records, I presume that every diocese possesses a collection of wills which is worth calendaring. I am not sure that I have any great sympathy with wills, partly from prejudice, but the recent publication by Dr. Sharpe, of the Calendar of Wills, registered in the Court of Hustings, of the city of Lundon, has made me rather change my mind. Certain it is that you occasionally get charming little particulars of the manner and customs of the times. I take leave to illustrate this by an extract from a register of wills kept in my own parish of St. Christopher le Stocks. There is among the number a will in the fifteenth century, whereby one John Plonket gave certain lands to endow an obit. I was not aware that the customs of the city of London necessitated any particular formula in the execution of a will with such a provision, but from the extract I am about to give it would seem that this was the case. At the end of John Plonket's will there is the following note :-

"This testament of John plonket Shereman of the lands and tenements for the sowle of John Gedney etc. to Mortuary vse as bequethed was sealid by the same John 
plonket the xiiijt daie of the moneth of ffebruary In the yere of our Lorde god $\mathrm{m}^{\circ} \mathrm{c} \mathrm{c} \mathrm{c}$ c lxxxiij And in the first yere of the Reign of King Richard the thirde (that ys to say) on the day of saint Valentine the martir bitwene the houres of fyve and sixe of the Clok at aftir noone of the same daie within the Chirche of saint Christofer within wretyn in the north ysle of the same chirche with a seale of laten gilted graven with a lef callid a trefoyle The same John plonket than amongs other stondyng in the same north Isle of the said chirche wering than a gowne of wollen cloth of Russet colour and a blak hat on his hed, with a blak typpet of wollen cloth about his neck than and there being present the worshipfull man Mr. William Stokker knight and the discret personnes William Holme Thomas Rerisby James Wellys, Drapers, Richard Eryk, vpholder, Reynold Ruttor John Croke thoinger, Roger Acheley, Dripers, Robert Eyrk, ffelmonger, John Ginswell and John fforster witnessies on to the premissies callid and specially Required."

$\mathrm{Up}$ to this time I have been speaking exclusively of matters in England, but I must be permitted to say a few words about foreign countries, and as I am speaking about records I will begin by speaking about foreign records.

I wish to mention a field which has not been, as far as I know, much explored, but which contains abundant materials for future Antiquaries-I mean the records of the Cathedrals in Spain. 'I he Spanish clergy are always willing to show strangers their libraries and muniment rooms, and nothing is more distressing than to see the complete manner in which the records of their properties were kept, in many cases the completeness of the records, aud then to remember that the whole of the property has been confiscated. At one of the out-of-the-way cathedrals on the borders of Aragon and Castile I came across a record which is of great interest to an Englishman and reminds him of the intimate relations which existed in the twelfth and thirteenth centuries between this country and Spain. In visiting the cathedral of Siguenza last autumn, which is of itself a building of great interest, I learnt from Murray's Handbook that there had been a chapel in the cathedral dedicated to St. Thomas of Canterbury. On inquiring from the Canon in residence $I$ found that not 
only was this the case, but that they had in the cathedral a contemporary account of the murder of Thomas Becket, which he believed had been presented to the cathedral by a Bishop named Jocelin. The Canon did not know who Bishop Jocelin was, or the manner in which he happened at Siguenza, but the date was 1208 .

The following seems to be the history :-Eleanor, or as she is called in Spain, Leonora, one of the daughters of King Henry $\Pi$. of England, married Alonzo, King of Castile. Jocelin, Bishop of Bath, had been a friend of King Richard, her brother, and was in the confidence of King John. King John promoted him to the Bishropic of Bath. In the quarrel which the King had with the monks of Canterbury the Pope put the kingdom under an interdict. One of the Bishops who had to publish this was Jocelin. Having publisherl it, he ran away, and went first to Bordeaux and aftewards to the King's sister, Eleanor, at Burgos, and accompanied her and her husband to Siguenza when the cathedral was dedicated. He took the opportunity of leaving there a record of Thomas Becket's murder, which is still preserved in the cathedral archives. The Canon told me that he intended to publish this document, and I told him I would assist him if he wished; but by 1208 the account of Thomas Becket's murder must have been stereotyped, and so that but for the interest of the thing I do not expect any new light would be thrown upon the transaction by its publication. In passing you will not forget that this Bishop Jocelin was a contemporary and friend of Archbishop Hubert Walter, of whom we have spoken of already. There are other churches and chapels in Castile dedicated to Thomas Becket, and no doubt an investigation of each case would produce a history as interesting as that I have just told, but here again I am treading on the limits.

In a little tumble-down, out-of-the-way town, between Seville and Huelva, at the south-west corner of Spain, named Niebla, on the Rio Tinto, a town both in its present and past circumstances not unlike Winchelsea, I found an interesting series of records consisting of the charters granted to the town in the thirteenth century by Alonzo el Sabio, the son of San Fernando, and contemporary and friend of our King Edward I. 
These charters are in Spanish, and reminded me of the observation made by the Bishop of Oxford in one of his lectures on medirval history, to the effect that the English in negotiating a treaty with the Spaniards found that the Spanish diplomatists were unacquainted with any other language than their own, and the treaties which the English diplomatists had prepared in Latin had to be translated for the benefit of their Spanish colleagues into their own language.

It is interesting to observe that in one of these charters the Mohammedan Kings of Granada and Murcia, who were parties to the documents, are spoken of as vassals of the King of Spain-Rey de Granada, Vassallo del Rey, Rey de Murcia, Vassallo del Rey.

As we are now abroad I wish to turn to quite a different subject and country.

Some of you may have heard of the British School at Athens. I am going to speak of a portion only of its work-naturally that portion which is interesting to me. This institution has been doing a quiet and unostentatious but extremely valuable work for an Ecclesiastical Antiquary.

Young students at the school have been visiting the interesting churches scattered throughout the northern part of Greece and the Morea, and have been making very careful studies of them. These churches are of course in the highest sense interesting to the students of Oriental ecclesiology; they have never, as far as I know, been properly examined, much less illustrated. In some of the out-of-the-way Greek churches and monasteries, out of the way of the Turk, internal decorations and articles of furniture which cannot be found in any other part of the Levant are preserved.

The study of Oriental ecclesiology has been a plant of slow growth, but it has made some progress since the time when I, a lad, first visited those countries and was taken with it. Up to that time there was some general information, but Dr. Mason Neale's book upon the Orthodox Church of the East had not been written, and English students were dependent upon authorities who viewed the subject through Western spectacles.

'Ihe first great sympathetic writer was Dr. Mason Neale, VOI. XIVII 
and he has been followed in that part of his book which treats upon the Ecclesiastical Antiquities by various publications, principally French and German. Among these may be mentioned Count de Vogue's beautiful books. on Palestine and Syria, and the magnificent German publication of Saltzenberg. This book gives plans and elevations of a few of the Christian buildings still remaining in Constantinople, but its main object was to describe the church of Aghia Sofia. Of the other Greek churches remaining in the town the writer does not mention more than six. To these have now to be added at least thirty. Some of these have been described by an Austrian architect, named D. Pulger, but by far the greatest authority upon the subject is my friend, Dr. Paspati, the greatest Byzantine Antiquary living the world has.

One of the most interesting features in a Greek church is the picture-screen, or ikonostatis. This screen, which is a picturesque feature in every Oriental church, discharges an important function.

Its position is exactly that of the chancel rails of an English church, only an Oriental church invariably terminates in three apses, and this screen divides the apses from the body of the church. The three apses and the ikonostasis are intimately connected with every action in an Oriental Liturgy. The ikonostasis is one of the first things which strikes a western visitor in an Oriental church, and directs his attention to the difference between an Oriental and a Western Liturgy. This screen reaches to the vaulting of the church. To show how little is known upon the subject of this piece of eccleslastical furniture, I remember the late Dr, Stanley, the Dean of Westminster, on his return from Russia, informing me that he had been told there that the height of the ikonostasis was increased on each occasion of the Russians winning a province until it reached the present height. No doubt he had learned this from some high ecclesiastical authority in Russia, nevertheless it is not the fact. Since then the subject of Ecclesiastical Antiquities has been more studied in Russia, and a magnificent work upon the churches of Kieff has been published by the St. Petersburg Society of Antiquaries.

Among the discoveries recently made in Greece are two 
perfect specimens of the picture-screens in the church of St. Luke at Stiri. These picture-screens must be, I think, of the ninth or tenth century, and the discovery of them is of the highest interest. As I have explained on various occasions. at the Society of Antiquaries, I was fortunate enough to discover what I believe to be a portion of the screen of the Church of Aghia Sofia at Constantinople, and a considerable portion of the screen of a church now called the Mosque of the Callenders in the same city. I also identified two small portions of other screens, one in the Church of the Mone tes Choras, the Monastery in the Fields, and another in the Church of the Pantocrator, all at Constantinople. There is also a very small portion of the screen left in the Church of St. Sosipater at Corfu; sufficient to show that it was made, or at all events ornamented, with slabs of coloured marble. I think that these specimens together would enable one to reproduce to some extent what the general form and ornamentation of a picture-screen in a Greek church about the tenth century must have been. The screens in the seventeenth and eighteenth centuries were made of carved wood; there are many specimens of these remaining at Smyrna and throughout the Lievant. The modern screens are generally, made in imitation of classic designs.

The subject of this particular ornament of Greek ritual is one that is worthy of a great deal of study. There is no doubt that it was always intended as a screen to shut off the sanctuary from the rest of the building, answering to the altar rails in an English church. From the account given of the Church of the Apostles built by the Emperor Justinian at Constantinople, the altar was under the centre dome of the building, which was not unlike St. Mark's at Venice in shape. There was a screen which enclosed the altar in what was then and is still called the Isparsiov, or sanctuary. Professor Hayter Lewis told me that he had visited a few days since, just outside the Damascus Gate of Jerusalem, a church which was being excavated by some Americans. In this church he found the traces of a screen enclosing the eastern apse of the church. In this case the church had only one apse. This fixes the date of the building as being not later than the reign of the 
Emperor Justinian; had it been later the church would have had three apses.

Unfortunately the energies of antiquaries in the east, when they have used them on excavation, have generally been addressed to uncovering classic temples; but there are three buildings which, if treated in this way, would I think give us some valuable information upon the subject of which I am speaking. In the first place there is the ruined Church of St. John at Ephesus, which I myself on one occasion tried to operate on with this particular object, but failed through the jealousy of the Greek population. There is another church, opposite Laodicea in Hierapolis, which, from its proximity to the line of the Ottoman railway, can without difficulty be investigated, and a still more distant church on the same railway, at Dineir, the ancient Apamea. These two latter churches have never been used by the Mohammedans as mosques, but were destroyed partly by time and partly by earthquake, so I should expect to find some sufficient traces of the screen in each of them. It is not unlikely that a similar discovery would be made in the church at Ephesus. This would be the most interesting of the three. The Church of St. John at Ephesus was built in imitation of the Church of the Apostles at Constantinople. The altar no doubt stood under the central dome, and most probably sufficient would be found of it to show what the arrangements of the screen round the sanctuary was like. At all events the British School at Athens have made the first start. I should like to think that I should be able to follow up the investigation; I am afraid I must content myself by showing what has been done, and how one of the most interesting and one of the least known objects of ecclesiastical furniture in the east can be investigated.

Two gentlemen from the school are now about to visit Salonica and Mount Athos. At the former they will find abundant material to irterest them. I do not think they will find any traces of the ikonostasis in any of the churches, but there are five marble reading-desks or ambones of different forms now lying in the courtyards of the churches and mosques to which they belonged. As far as I know only one of these has ever been drawn, though I have photographs of all of them. I am afraid 
that the demon of restoration has penetrated even to Mount Athos, and I do not expect they will find many remains in the direction in which I have been speaking, but they will find other deeply interesting details, and these monasteries, though often visited by English, have never yet been examined by a skilled architect or indeed at all satisfactorily. I hope that the funds of the society will enable it to publish the result of these researches.

I do no like to leave Greece without mentioning another great discovery which has recently been made. In the Plain of Marathon there is a large mound; tradition pointed this out as the site of the burial-place of the Greeks who fell at the celebrated battle, but the discovery some forty years ago of stone arrow heads in the mound, decided antiquaries that this monument belonged to an earlier age and was existing at the time of the battle.

Within the last few weeks the mound has been fully examined, and tradition has, as it generally does, vindicated itself. In the middle of the mound were found a series of interments which have gone far to establish the fact that this is the tomb of the Greeks who perished in that battle. The investigations are still being continued, but I have no doubt they will satisfactorily prove the truth of the tradition, and the history of the battle will again have to be written. Recent historians have assumed that the mound was existing at the time of the battle, and have accordingly shifted the position of it.

While speaking of foreign matters it would not be right not to mention the efforts that have been made to stop the destruction of antiquities in Egypt. Unfortunately England seems to me to be behind other nations in the protection of objects of antiquity. We never have succeeded in protecting them in our own country, and from what I hear it seems doubtful if we have been or shall be able to protect them in India, and it is hardly probable we shall be more successful in Egypt. Something however the Society of Antiquaries has been doing in this direction, and it may be hoped that at all events we shall leare the antiquities of Egypt, if and when we do vacate that country, in no worse condition than we found them. This is, I think, saying a good deal, for wherever the English go, and there is safety for travellers, there must 
follow a certain class of English-speaking persons who do not like not to leave some remembrance of them behind. Either they will cut their names, and this is the most harmless, or they will carry off souvenirs, which is worse. Any one who knows Bishop Fox's monument in Winchester Cathedral can, as I can, testify to the destruction that our own folk and our American cousins every year cause in the carved work which ornaments it.

The preservation of antiquities brings me to mention our own. I am bold enough now to say a few words about the preservation of ancient monuments in England. In a crowded country such as this is antiquities must be constantly destroyed, there is no help for it. The cultivation of the ground destroys old roads, earth-works and sepulchral mounds.

With regard to churches it must never be forgotten that the Church of England is a going concern, and churehes must be kept up and enlarged. It has always been so. It is no doubt very much to be regretted that the nineteenth century has no style of architecture of its own, and apparently has no means of making one. The consequence is we must content ourselves with copying some older style for church building. This also leads to the attempt to restore, but this cannot be helped. The Church of England cannot stand still to suit the wishes of us antiquaries. The utmost we can hope to do is to improve the taste of those to whom the care of. a church is entrusted. But this is very uphill work, and the more distinguished the architect is the less is he tolerant of interference. I commend to your notice the chapel of Winchester College and the church of St. Cross, near the same city, as examples of how an ecclesiastical brilding should not be treated; and yet the architect who carried out these works is a man of the highest position and ability, but no great lover of antiquities.

Secular objects of antiquity, unless they can be made useful, generally get improved away altogether. When I first remember, a great portion of the wall of the City of London could be seen; now I only know of three small portions. The most important secular buildings belong to municipal authorities, and these are not generally good antiquaries, and it is very little that we can do to 
preserve a record of it. It can be photographed, drawn and measured - this is the next best thing to being able to preserve the original.

I hear with pleasure that the municipal authorities at Leeds have consulted our good friend Mr. Micklethwaite about the preserving of Kirkstall Abbey. They have already had a most excellent report from another friend of ours; Mr. St. John Hope, the learned and at the same time most obliging assistant secretary of the Society of Antiquaries of London. They could not have done better than consult these two. Only I hope Mr. Micklethwaite will recommend it to be repaired and utilized as the cathedral of the town. It is many years since I saw it, forty I think, but it looked then as if it might have been repaired. I. am very sceptical about the preservation of ruins, except they be Roman, in which case their durability enables them to preserve themselves. Ruins must go, particularly gothic ruins. I believe an Indian proverb says that an arch never is at rest. All we can hope to do is to keep an accurate account of them by excavation, measurements, and drawing, and by a liberal use of photography.

As a rule local societies discharge their duty with regard to ancient monuments in a satisfactory manner, and $I$ have no doubt the Societies of Gloucester and Bristol are no exceptions. I only hope that when a building is doomed they will have an accurate record kept of it.

And now I wish to touch on another subject which especially interests me. How can we all be Antiquaries? I see here educated people of all sorts, some of them real Antiquaries, some of them only taking the subject up, as I do, as a pastime, and some others are here only like the men. of Athens-curious to hear some new thing. To the two former classes I need say nothing, to the latter I would say with the Roman poet, though in a very different connexion - "Macte virtute puer."

The real way to become an antiquary is to follow up. that subject which comes to a man's hand. We all of us live in a town or village, and most of us have a profession or business. There is no town or village in England that has not its own history; there is no trade or business a man follows that cannot teach the person who follows it some-. 
thing of history and its own antiquity. Let each man take that which comes to his hand, and he will soon find how far reaching is the study of antiquities in his own person.

I may perhaps introduce some of my personal experiences. Circumstances in my youth took me to the Levant, and my first lessons in antiquarian studies were there. These were my first and consequently my most agreeable studies, and whenever I can, I revert to them. When I came to my own business it was not unnatural that the antiquities of my own profession should occupy some part of my thoughts. The subject is not an inviting one, but, nevertheless, it has a very curious interest of its own.

In time I became a churchwarden of a city parish. I had no fancy for this post, and parochial matters were distasteful to me, but it fell out in the way of business, and those who know my life for the last twenty years know how completely I have thrown in my lot with my enforced position, and how much instruction, pleasure, and satisfaction I have derived from it. As I walk through the parish in which my place of business is, I know every inhabitant in it from the middle of the sixteenth century and where he lived and what he did.

In the course of events I became a member of, and ultimately master of, the Worshipful Company of Scriveners of the City of London. This Company is the College of Notaries of London, and as you may imagine, when I was able to do so, I examined their records and found among them a complete list of the city notaries and of their notarial marks from the reign of King Edward II. to the present time, and a very interesting record it is.

But whenever leisure comes to me I go back to my first love. I never could have believed that I could have interested myself in parochial and municipal records; but they came to my hand, and they have interested and engrossed my attention more than I could have expected or believed.

I would therefore urge upon all my friends here, and particularly those who are commencing the study of antiquities, to take up that subject which comes across them in their daily path, and I would like to wind this address up with another personal experience. I live in Surrey, at 
the top of the North Downs. One day while I was churning this address in my mind I went for a walk over Walton Heath. Any Surrey person knows this as the finest heath in Mid-Surrey. In the middle of the heath is a Roman summer camp, with the colonel's house adjoining it. Somehow my steps naturally took me there. It was an out-of-the-way part of the heath, and I had something of a scramble to find my way home.

As I walked across the heath I thought of how there are antiquities worthy of study in every man's path if he would only look for them, and I determined in my address to impress it on you here to-day. Almost as it were in fulfilment of my own idea, in the middle of the heath I came suddenly upon the traces of an ancient Roman way which I knew must be there, which I had long looked for and always missed; and as I looked along it, and traced the faint remains of it covered with heather, the thought came doubly strong upon me-there are abundant opportunities for the study of antiquities in the path of everyday life which is before you if you will only keep your eyes open and avail yourself of them.

I have only one more word. I have made this address personal to give encouragement to others who, like myself, have very few, if any, really leisure hours. If I with so little leisure have found so much instruction and real pleasure from the study, what may not others of you get from it who have more time at your disposal than I have? 